\title{
Application of Microsatellite Loci for Molecular Identification of Elite Genotypes, Analysis of Clonality, and Genetic Diversity in Aspen Populus tremula L. (Salicaceae)
}

\author{
Dmitry V. Politov, ${ }^{1}$ Maryana M. Belokon, ${ }^{1}$ Yuri S. Belokon, ${ }^{1}$ \\ Tatyana A. Polyakova, ${ }^{1}$ Anna V. Shatokhina, ${ }^{1}$ Elena A. Mudrik, ${ }^{1}$ Anna B. Azarova, ${ }^{2}$ \\ Mikhail V. Filippov, ${ }^{2}$ and Konstantin A. Shestibratov ${ }^{2}$ \\ ${ }^{1}$ Vavilov Institute of General Genetics, Russian Academy of Sciences, Gubkin Street 3, Moscow 119991, Russia \\ ${ }^{2}$ Shemyakin \& Ovchinnikov Institute of Bioorganic Chemistry, Russian Academy of Sciences, Pushchino Branch, \\ Pushchino 142290, Russia
}

Correspondence should be addressed to Dmitry V. Politov; dmitri.p17@gmail.com

Received 31 October 2015; Accepted 2 December 2015

Academic Editor: Viktor Korzun

Copyright (C) 2015 Dmitry V. Politov et al. This is an open access article distributed under the Creative Commons Attribution License, which permits unrestricted use, distribution, and reproduction in any medium, provided the original work is properly cited.

\begin{abstract}
Testing systems for molecular identification of micropropagated elite aspen (Populus tremula L.) genotypes were developed on the base on microsatellite (SSR) loci. Out of 33 tested microsatellite loci, 14 were selected due to sustainable PCR amplification and substantial variability in elite clones of aspen aimed for establishment of fast-rotated forest plantations. All eight tested clones had different multilocus genotypes. Among 114 trees from three reference native stands located near the established plantations, 80 haplotypes were identified while some repeated genotypes were attributed to natural clones which appeared as a result of sprouting. The selected set of SSR markers showed reliable individual identification with low probability of appearance of identical aspen genotypes (a minimum of $4.8 \cdot 10^{-10}$ and $1 \times 10^{-4}$ for unrelated and related individuals, resp.). Case studies demonstrating practical applications of the test system are described including analysis of clonal structure and levels of genetic diversity in three natural aspen stands growing in the regions where plantations made of elite clones were established.
\end{abstract}

\section{Introduction}

The continued degradation of native forests worldwide due to the overexploitation requires introduction of intensive forms of forestry that would favor not only economic effect but also conservation of woody plant genetic resources. This task declares obtaining and maintenance of elite genotypes of forest trees aimed for fast-rotated forest plantations. New highly productive and sustainable to abiotic factors, pests and pathogens cultivars and varieties appear as a result of breeding, selection of mutations, and/or genetic engineering. The clonal propagation of such outstanding individuals ensures fixation of their useful traits both for further breeding experiments and for establishment of targeted forest plantations. In particular, microclonal propagation via in vitro culture allows for rapid, large-scale, and cost-effective cloning of individuals with desired traits especially when traditional budding or grafting is impossible or requires special efforts [1-3].

Since morphologically and anatomically different plant clones may look similar, it is essential to reliably identify those including discrimination from each other and from conspecific individuals or representatives of other closely related species. In forestry, the problem of individual identification is especially crucial since the external look of trees is highly dependable on environmental parameters [4]. At particular stages of natural ontogenesis of forest trees, for example, seedlings and saplings, and especially as calluses or explants in vitro cell culture, individuals may be indiscernible not only individually but also as far as species diagnoses are concerned. Long generation time and ontogenetically late maturation makes the task of genetic passportization of elite clones in woody plants real. The complex multistage process 
of obtaining, propagation, and introduction of elite cultivars by breeding or genetic engineering increases the probability of various errors.

Molecular genetic markers (MGM) proved to be very efficient tools for individual identification. Among different MGM classes microsatellites or simple sequence repeats (SSR) fit best to requirements of testing systems for identification due to their specificity, codominance, selective neutrality, sufficient allelic richness, and heterozygosity caused by high mutation rate. Moreover, due to relative genome conservatism within genera and families of plants, SSR-markers and PCR primers for their amplification can be transferrable from one taxon to another.

In several poplar species, the successful DNA fingerprinting and differentiation of clones, cultivars, and varieties were demonstrated by molecular markers including SSR loci [5-9].

In this paper we report on the development of SSRbased testing system for molecular genetic identification of elite micropropagated genotypes of aspen, Populus tremula L., aimed at the establishment of fast-growing target forest plantations in several regions of Russian Federation and present the results of its application for individual genotypes discrimination, studies of clonal structure in natural aspen stands, and estimation of genetic variability in populations.

\section{Material and Methods}

The development of the testing system for the identification of elite genotypes comprised the selection of a specific marker set fitting the requirements of high-resolution discrimination of clones and testing its reliability and identification power on a set of elite genotypes and a sufficient number of representatives of a studied species.

2.1. Plant Material. Elite aspen and hybrid clones used for development of testing systems for molecular identification have been obtained from micropropagated cell cultures [10] maintained in the Pushchino branch of Shemyakin and Ovchinnikov Institute of Bioorganic Chemistry, Russian Academy of Sciences (Pushchino, Russia). Origin and short description of eight clones are presented in Table 1.

Experimental aspen clonal plantations derived from these elite genotypes were established in four regions of European part of Russia (Figure 1). Native aspen stands located closely to these plots were used for studies of clonal structure, evaluation of frequencies of multilocus genotypes, and calculations of probabilities of appearance of identical allelic combinations in a single genotype.

Prisady. Experimental plot located $1 \mathrm{~km}$ westward of settlement Prisady in Serpukhovsky Raion (district) of Moscow oblast' (Russia). Leaves of 52 young or medium-aged (approximately 10-25 y.o.) aspen trees from a natural multiaged stand located in close proximity $(1 \mathrm{~km})$ to this plot have been used as a reference population.

Voronezh. Seventeen trees were sampled in a stand adjacent to the experimental plot established in Voronezh Oblast.

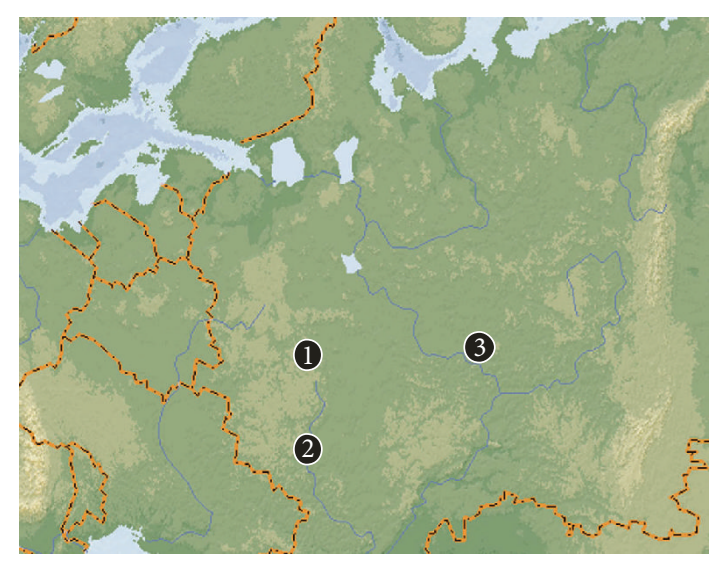

FIGURE 1: Map of location of plantations made of elite clones and corresponding native aspen stands used as reference populations. (1) Prisady, (2) Voronezh, and (3) Yoshkar-Ola.

Additional 13 trees were collected along the bank of Voronezh River within the city of Voronezh close to the plantation.

Yoshkar-Ola. Young native stand of aspen was the source of trees used as a reference population for an experimental plot located near the city of Yoshkar-Ola, Republic of Mari-El. Leaves from 32 trees were collected.

In order to minimize the occasional sampling of individuals having vegetative origin (through sprouting) we collected leaves from trees at a distance not less than 15-20 m from each other. This approach was employed for inclusion into reference samples of predominantly open-pollinated seedlings having maximal genetic diversity. However, based exclusively on external look of the trees and distance among them, sampling of the ramets appearing as a result of sprouting could not be avoided, and subsequent genetic analysis confirmed this.

Shoots with leaves were cut off by means of mechanical cutter with an aluminium telescopic mast. Collected shoots with leaves were placed into plastic bags for no more than 6 days at $+4^{\circ} \mathrm{C}$ until processing. Sample preparation included DNA extraction and placement of reserve leaf tissue fragments into labeled zip-bags with silica gel for long-term storage. Outside the period of active vegetation, dormant vegetative buds can be successfully used for DNA extraction.

2.2. DNA Extraction. Fragments of leaves approximately $350-500 \mathrm{mg}$ taken from explants growing in vitro on a special media (REF) in Petri dishes were used for DNA extraction.

For trees from native populations, we extracted DNA from 350-500 mg fragments of fresh or 200-300 mg of silicadried leaf tissues by a modified cethyltrimethylammonium bromide (CTAB) method $[13,14]$.

2.3. Microsatellite Analysis. Microsatellites, or SSR, represent a class of tandemly repeated DNA sequences with short (16 pairs of nucleotides, bp) motifs differing in copy numbers among individuals due to high mutation rate. Multiple alleles usually found in codominant microsatellite loci create a great 
TABLE 1: Elite aspen and hybrid clones and their characteristics.

\begin{tabular}{|c|c|c|c|c|}
\hline $\begin{array}{l}\text { Original } \\
\text { genotype }\end{array}$ & $\begin{array}{c}\text { Putative } \\
\text { species/hybrid } \\
\text { identity }\end{array}$ & Origin & Description & $\begin{array}{c}\text { Clones and clonal lineages } \\
\text { obtained based on original } \\
\text { genotypes }\end{array}$ \\
\hline PtV22 & $\begin{array}{c}\text { Putatively } \\
\text { Populus tremula }\end{array}$ & $\begin{array}{l}\text { Minsk Oblast, Belarus, breeding } \\
\text { form obtained in Institute of } \\
\text { Forest, National Academy of } \\
\text { Belarus, Gomel, Belarus, } \\
\text { provided by V. E. Padutov }\end{array}$ & $\begin{array}{l}\text { Diploid green-bark aspen form. } \\
\text { Characterized by fast growth and } \\
\text { resistance to heart rot caused by } \\
\text { pathogen fungus Phellinus } \\
\text { tremula }\end{array}$ & $\begin{array}{l}\text { Ptv22-1, Ptv22-2, Ptv22-3, } \\
\text { 21mut, 2mut, } 14 \text { mut, } 4 \text { mut, } \\
\text { 12mut }\end{array}$ \\
\hline $\mathrm{Pt}$ & P. tremula & $\begin{array}{l}\text { Leningrad Oblast, Russia, } \\
\text { breeding form obtained in St. } \\
\text { Petersburg Research Institute for } \\
\text { Forestry, provided by D. A. } \\
\text { Shabunin }\end{array}$ & $\begin{array}{l}\text { Diploid giant aspen form. } \\
\text { Characterized by fast growth and } \\
\text { resistance to heart rot caused by } \\
\text { pathogen fungus Phellinus } \\
\text { tremula }\end{array}$ & $\mathrm{Pt} 2, \mathrm{Pt} 3$ \\
\hline $\mathrm{F} 2$ & P. tremula & $\begin{array}{l}\text { Kostroma Oblast, Russia, } \\
\text { breeding form obtained by S. N. } \\
\text { Bagayev, provided by D. A. } \\
\text { Shabunin }\end{array}$ & $\begin{array}{l}\text { Diploid female clone. Highly } \\
\text { productive (plus } 51 \% \text { by sum of } \\
\text { stem cross section squares and } \\
\text { plus } 43 \% \text { by growing stock). } \\
\text { Increased wood density of } \\
475 \mathrm{~kg} / \mathrm{m}^{3}[11]\end{array}$ & F2-1, F2-2, F2-3 \\
\hline 47 & P. tremula & $\begin{array}{l}\text { Latvian State Forest Research } \\
\text { Institute "Silava," Latvia, } \\
\text { provided by Dr. Arnis Gailis }\end{array}$ & $\begin{array}{l}\text { Diploid aspen form. Productivity } \\
\text { of } 180-200 \mathrm{~m}^{3} / \text { haat age } 12 \text { under } \\
\text { density of } 1100 \text { stems/ha. } \\
\text { Characterized by resistance to } \\
\text { heart rot caused by pathogen } \\
\text { fungus Phellinus tremula [12] }\end{array}$ & $\begin{array}{c}47-1,47-1-1-31,47-1-1-22 \\
47-1-2-27,47-1-1-19 \\
47-1-2-53\end{array}$ \\
\hline C-control & $\begin{array}{l}\text { P. tremuloides } \times \\
\text { P. tremula }\end{array}$ & -“- & $\begin{array}{l}\text { Diploid hybrid form. } \\
\text { Productivity of } 180-200 \mathrm{~m}^{3} / \text { ha at } \\
\text { age } 12 \text { under density of } \\
1100 \text { stems/ha [12] }\end{array}$ & $C-1, C-2, C-3$ \\
\hline 23 & $\begin{array}{l}\text { P. tremuloides } \times \\
\text { P. tremula }\end{array}$ & -“- & $\begin{array}{l}\text { Diploid hybrid form. Maximal } \\
\text { productivity of } 200-250 \mathrm{~m}^{3} / \text { ha } \\
\text { demonstrated at age } 12 \text { under } \\
\text { density of } 1100 \text { stems/ha [12]. } \\
\text { High wood density }\end{array}$ & L23-1, L23-2, L23-3 \\
\hline 4 & $\begin{array}{l}\text { P. tremuloides } \times \\
\text { P. tremula }\end{array}$ & -“- & $\begin{array}{l}\text { Maximal productivity of } \\
250-300 \mathrm{~m}^{3} / \text { ha demonstrated at } \\
\text { age } 12 \text { under density of } \\
2500 \text { stems/ha [12] }\end{array}$ & L4-1, L4-2, L4-3 \\
\hline $\begin{array}{l}\text { No. 3- } \\
\text { understory }\end{array}$ & P. tremula & $\begin{array}{l}\text { Republic of Tatarstan, breeding } \\
\text { form by A. H. Gaziulllin, } \\
\text { provided by N. R. Garipov }\end{array}$ & $\begin{array}{l}\text { Triploid aspen form. } \\
\text { Characterized by fast growth and } \\
\text { resistance to heart rot caused by } \\
\text { pathogen fungus Phellinus } \\
\text { tremula }\end{array}$ & No. 3-understory-1 \\
\hline
\end{tabular}

variety of unique genotypic combinations which ensures their reliable identification, especially when a sufficient number of loci are employed. Technically, the analysis of SSR polymorphism requires only Polymerase Chain Reaction (PCR) and subsequent electrophoresis (gel or capillary) for fragment analysis. For the development of the testing system we chose the variant of the method that utilizes only basic equipment and simple reagents. This ensured increased reproducibility of the procedures in any PCR laboratory and allowed achieving high cost-effectiveness of the analysis which is crucial for large-scale practical clone identification.

Since the substantial number of nuclear SSR loci for poplars was found in the literature and primer databases we decided to select from several publications and test primers that can be used for routine genotype identification based on very simple equipment without using of DNA-analyzers. An initial set of SSR primers for their potential use as elements of the testing system of molecular identification in aspen was a result of search in bibliographical databases (Thomson Reuters Web of Science, http://webofknowledge.com/) and in Molecular Ecology Resources Primer Database (http://tomato.bio.trinity.edu/).

DNA amplification was performed using PCRCore kits (Isogen Laboratories, Ltd., Moscow, Russia) in BioRad Inc. (USA) Dyad Thermo cycler. Microsatellite loci (listed in Table 2) from series ORPM [15] and WPMS [16] were amplified with specific primers at concentration of $1 \mathrm{mmol} / \mathrm{mL}$ and 5-10 ng of target DNA using the following temperature 
TABLE 2: Microsatellite loci tested for PCR amplification in aspen.

\begin{tabular}{|c|c|c|c|}
\hline Loci & Primer sequences $\left(5^{\prime}-3^{\prime}\right)$ & Repeat motif & Fragment size $(\mathrm{bp})^{3}$ \\
\hline ORPM14 & $\begin{array}{l}\text { F- GGGCTGCAGCAGATATTGA } \\
\text { R- CCAAAGGAACCCAAAGAAGA }\end{array}$ & $(\mathrm{GCTC})_{4}$ & $146-162$ \\
\hline ORPM18 $^{1}$ & $\begin{array}{l}\text { F- AGCAGAGATCGATGCTGAGG } \\
\text { R- AATTTCTCGCTTCTCGCATT }\end{array}$ & $(\mathrm{TTTA})_{4}$ & 205 \\
\hline $\mathrm{ORPM}^{3} 6^{1}$ & $\begin{array}{l}\text { F- AGCCTCCAAACACCATGAAC } \\
\text { R- ACAGTGGTGTGGATCCTGCT }\end{array}$ & $(\mathrm{GAAA})_{4}$ & 213 \\
\hline ORPM $60^{1}$ & $\begin{array}{l}\text { F- ATAGCGCCAGAAGCAAAAAC } \\
\text { R- AAGCAGAAAGTCGTAGGTTCG }\end{array}$ & $(\mathrm{AAT})_{5}$ & 212 \\
\hline ORPM79 $^{1}$ & $\begin{array}{c}\text { F- GAAGCTGAAAACAACAACAAACA } \\
\text { R- GGGTTTTTAACATAATAAAAGCTTGG }\end{array}$ & $(\mathrm{AAT})_{4}$ & 160 \\
\hline ORPM81 $^{1}$ & $\begin{array}{l}\text { F- GCTGCAGCCAAACAAAGC } \\
\text { R- CAGAAATCCCACCCAAACC }\end{array}$ & $(\mathrm{TATT})_{4}$ & $142-158$ \\
\hline ORPM $84^{1}$ & $\begin{array}{l}\text { F- CTGCAGCCTTACCACCATTT } \\
\text { R- CGTGTTCGAGATTGGGATTT }\end{array}$ & $(\mathrm{AAG})_{4}$ & 171 \\
\hline ORPM $86^{1}$ & $\begin{array}{l}\text { F- CCACATCCATAGCTCTGCAAC } \\
\text { R- GTACTACCTCGCCTGCCAAC }\end{array}$ & $(\mathrm{CTT})_{5}$ & 204 \\
\hline ORPM107 $^{1}$ & $\begin{array}{l}\text { F- AATCTGGTGGCTTGCCTCT } \\
\text { R- TTGAGGAACACGTGCAGACT }\end{array}$ & $(\text { TAAA })_{4}$ & 190 \\
\hline ORPM117 $^{1}$ & $\begin{array}{l}\text { F- CCCCCTAATTACCTTGGAAAC } \\
\text { R- TTGTTTGTATCTCCTCCGTTGA }\end{array}$ & $(\mathrm{ATTA})_{4}$ & 210 \\
\hline ORPM158 ${ }^{1}$ & $\begin{array}{l}\text { F- GCTGAAACATCCTTCATGGTC } \\
\text { R- CGAAGCTGCATAAGCATCAA }\end{array}$ & $\left(\mathrm{TTTC}_{4}\right.$ & 200 \\
\hline ORPM193 $^{1}$ & $\begin{array}{l}\text { F- CCGCTGGATTTGTTTGTTTT } \\
\text { R- TGAGCAGAAAGATGCGAAGA }\end{array}$ & $(\mathrm{ATTTT})_{4}$ & $187-207$ \\
\hline 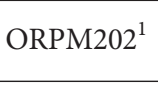 & $\begin{array}{l}\text { F- TCGCAAAAGATTCTCCCAGT } \\
\text { R- TTCAAATCCCGGTAATGCTC }\end{array}$ & $(\mathrm{TAA})_{5}$ & $184-190$ \\
\hline ORPM $^{2} 06^{1}$ & $\begin{array}{l}\text { F- CCGTGGCCATTGACTCTTTA } \\
\text { R- GAACCCATTTGGTGCAAGAT }\end{array}$ & $(\mathrm{GCT})_{7}$ & $190-208$ \\
\hline $\mathrm{ORPM}_{220^{1}}$ & $\begin{array}{l}\text { F- AGCTAGCCTGTCGTCAAGGA } \\
\text { R- CAAGGAAGCATTCTCGCAAT }\end{array}$ & $(\mathrm{TTTA})_{6}$ & $178-222$ \\
\hline ORPM $296^{1}$ & $\begin{array}{l}\text { F- CGAAGCCATTGACCCAGTAT } \\
\text { R- GGGCATCTCTCTCCTTTCAA }\end{array}$ & $(\mathrm{GTTCTG})_{4}$ & 199 \\
\hline ORPM $312^{1}$ & $\begin{array}{c}\text { F- GTGGGGATCAATCCAAAAGA } \\
\text { R- CCCATATCAAACCATTTGAAAAA }\end{array}$ & $(\mathrm{CCT})_{6}$ & 194 \\
\hline ORPM $366^{1}$ & $\begin{array}{l}\text { F- CCTTGAGGGGACACTTCGAT } \\
\text { R- AAAGAGTTGAGCCCTTGGTG }\end{array}$ & $(\mathrm{TTA})_{5}$ & 156 \\
\hline 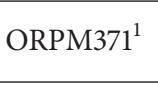 & $\begin{array}{l}\text { F- CCGGACTCTCACAAATCTCC } \\
\text { R- TGCTTTTGCTCCTGGTTCTT }\end{array}$ & $(\mathrm{TCTT})_{6}$ & $192-200$ \\
\hline $\mathrm{ORPM} 372^{1}$ & $\begin{array}{l}\text { F- AGCTCTTCTGCTGGTGCTGT } \\
\text { R- GAGGGAGGGAGGGTAAAAGA }\end{array}$ & $(\mathrm{TCTT})_{5}$ & 190 \\
\hline ORPM $415^{1}$ & $\begin{array}{l}\text { F- CTCGGTGCAAATATCGGTTC } \\
\text { R- AGATCGATGGTCCTTTCCTG }\end{array}$ & $(\mathrm{GGCG})_{4}$ & 225 \\
\hline ORPM $484^{1}$ & $\begin{array}{l}\text { F- CAAAATGGCAATCCAAGGTT } \\
\text { R- CCAAGCTTCCAATTGAGTCC }\end{array}$ & $(\mathrm{TTAA})_{4}$ & 190-206 \\
\hline ORPM $488^{1}$ & $\begin{array}{l}\text { F- CTCCAGCCGCTTCTATCCTT } \\
\text { R- TGTCGTGGGAAAGAACCAGT }\end{array}$ & $(\mathrm{TTA})_{6}$ & 200 \\
\hline ORPM $496^{1}$ & $\begin{array}{l}\text { F- CAGCAGTGCAAGCTCCTAAA } \\
\text { R- GGCCACTGACAGAGACCAAG }\end{array}$ & $(\mathrm{GGA})_{4}$ & 185 \\
\hline $\mathrm{WPMS}_{14}{ }^{2}$ & $\begin{array}{c}\text { F- CAGCCGCAGCCACTGAGAAATC } \\
\text { R- GCCTGCTGAGAAGACTGCCTTGAC }\end{array}$ & $(\mathrm{CGT})_{28}$ & $215-287$ \\
\hline WPMS15² & $\begin{array}{c}\text { F- CAACAAACCATCAATGAAGAAGAC } \\
\text { R- AGAGGGTGTTGGGGGTGACTA }\end{array}$ & $(\mathrm{CCT})_{14}$ & 201-219 \\
\hline
\end{tabular}


TABLE 2: Continued.

\begin{tabular}{|c|c|c|c|}
\hline Loci & Primer sequences $\left(5^{\prime}-3^{\prime}\right)$ & Repeat motif & Fragment size $(\mathrm{bp})^{3}$ \\
\hline WPMS16 ${ }^{2}$ & $\begin{array}{l}\text { F- CTCGTACTATTTCCGATGATGACC } \\
\text { R- AGATTATTAGGTGGGCCAAGGACT }\end{array}$ & $(\mathrm{GTC})_{8}$ & 139-184 \\
\hline $\mathrm{WPMS}^{2}$ & $\begin{array}{l}\text { F- ACATCCGCCAATGCTTCGGTGTTT } \\
\text { R- GTGACGGTGGTGGCGGATTTTCTT }\end{array}$ & $(\mathrm{CAC})_{15}$ & $122-146$ \\
\hline WPMS18 ${ }^{2}$ & $\begin{array}{l}\text { F- CTTCACATAGGACATAGCAGCATC } \\
\text { R- CACCAGAGTCATCACCAGTTATTG }\end{array}$ & $(\mathrm{GTG})_{13}$ & $219-248$ \\
\hline WPMS19 ${ }^{2}$ & $\begin{array}{l}\text { F- AGCCACAGCAAATTCAGATGATGC } \\
\text { R- CCTGCTGAGAAGACTGCCTTGACA }\end{array}$ & $(\mathrm{CAG})_{28}$ & $180-234$ \\
\hline WPMS $20^{2}$ & $\begin{array}{l}\text { F- GTGCGCACATCTATGACTATCG } \\
\text { R- ATCTTGTAATTCTCCGGGCATCT }\end{array}$ & $(\text { TTCTGG })_{8}$ & $210-222$ \\
\hline WPMS $21^{2}$ & $\begin{array}{l}\text { F- TGCTGATGCAAAAGATTTAG } \\
\text { R- TTGGAACTTCAACATTCAGAT }\end{array}$ & $(\mathrm{GCT})_{45}$ & $287-326$ \\
\hline WPMS22 2 & $\begin{array}{l}\text { F- ACATGCTACGTGTTTGGAATG } \\
\text { R- ATCGTATGGATGTAATTGTCTTA }\end{array}$ & $(\mathrm{TGA})_{23}$ & $100-135$ \\
\hline
\end{tabular}

Comments: ${ }^{1}$ Tuskan et al., 2004 [15]; ${ }^{2}$ Smulders et al., $2001[16] ;{ }^{3}$ by literature data in different Populus species (P. tremula, P. x canescens, and P. alba).

TABLE 3: Results of testing of microsatellite loci in aspen.

\begin{tabular}{|c|c|c|c|c|c|}
\hline Locus & PCR amplification & Fragment size range (bp) & Number of alleles & Status $^{1}$ & Included in testing system \\
\hline ORPM14 & Yes & $146-162$ & 4 & $\mathrm{P}$ & No \\
\hline ORPM18 & No & - & - & $\mathrm{N}$ & No \\
\hline ORPM36 & Yes & 217 & 1 & M & No \\
\hline ORPM60 & No & - & - & $\mathrm{N}$ & No \\
\hline ORPM79 & No & - & - & $\mathrm{N}$ & No \\
\hline ORPM81 & No & - & - & $\mathrm{N}$ & No \\
\hline ORPM84 & No & - & - & $\mathrm{N}$ & No \\
\hline ORPM86 & Yes & $204-216$ & 4 & $\mathrm{P}$ & No \\
\hline ORPM107 & No & - & - & $\mathrm{N}$ & No \\
\hline ORPM117 & Yes & 218 & 1 & M & No \\
\hline ORPM158 & Yes & 200 & 1 & M & No \\
\hline ORPM193 & Yes & $182-207$ & 6 & $\mathrm{P}$ & Yes \\
\hline ORPM202 & Yes & $184-193$ & 5 & $\mathrm{P}$ & Yes \\
\hline ORPM206 & Yes & $190-196$ & 3 & $\mathrm{P}$ & Yes \\
\hline ORPM220 & Yes & $178-198$ & 5 & $\mathrm{P}$ & Yes \\
\hline ORPM296 & Yes & 201-183 & 4 & $\mathrm{P}$ & Yes \\
\hline ORPM312 & Yes & 189-201 & 4 & $\mathrm{P}$ & No \\
\hline ORPM366 & No & - & - & $\mathrm{N}$ & No \\
\hline ORPM371 & Yes & $192-200$ & 3 & $\mathrm{P}$ & No \\
\hline ORPM372 & No & - & - & $\mathrm{N}$ & No \\
\hline ORPM415 & Yes & $\sim 280$ & 1 & M & No \\
\hline ORPM484 & Yes & $190-206$ & 3 & $\mathrm{P}$ & No \\
\hline ORPM488 & Yes & 197-203 & 2 & $\mathrm{P}$ & No \\
\hline ORPM496 & No & - & - & $\mathrm{N}$ & No \\
\hline WPMS14 & Yes & $224-243$ & 3 & $\mathrm{P}$ & Yes \\
\hline WPMS15 & Yes & $189-207$ & 5 & $\mathrm{P}$ & Yes \\
\hline WPMS16 & Yes & 139-184 & 9 & $\mathrm{P}$ & Yes \\
\hline WPMS17 & Yes & $122-146$ & 7 & $\mathrm{P}$ & Yes \\
\hline WPMS18 & Yes & $219-248$ & 7 & $\mathrm{P}$ & Yes \\
\hline WPMS19 & Yes & $210-252$ & 9 & $\mathrm{P}$ & Yes \\
\hline WPMS20 & Yes & $210-222$ & 4 & $\mathrm{P}$ & Yes \\
\hline WPMS21 & Yes & $196-240$ & 5 & $\mathrm{P}$ & Yes \\
\hline WPMS22 & Yes & $115-135$ & 3 & $\mathrm{P}$ & Yes \\
\hline
\end{tabular}

${ }^{1}$ P: polymorphic, M: monomorphic, and N: no PCR amplification.

profile: (1) initial denaturation at $94^{\circ} \mathrm{C}$ for $3 \mathrm{~min}$; (2) 30 cycles consisting of $30 \mathrm{sec}$ of denaturation at $94^{\circ} \mathrm{C}$, primer annealing at variable temperature and time (see Table 3 for final annealing temperature recommended after procedure adjustment), and elongation at $72^{\circ} \mathrm{C}$ for $1.5 \mathrm{~min}$ followed by
(3) final elongation at $72^{\circ} \mathrm{C}$ for $10 \mathrm{~min}$ and (4) chilling the PCR mixture to $4^{\circ} \mathrm{C}$.

PCR products were subjected to electrophoresis in $6 \%$ polyacrylamide gel blocks using Tris-EDTA-borate buffer system. After electrophoresis gels were stained in ethidium 


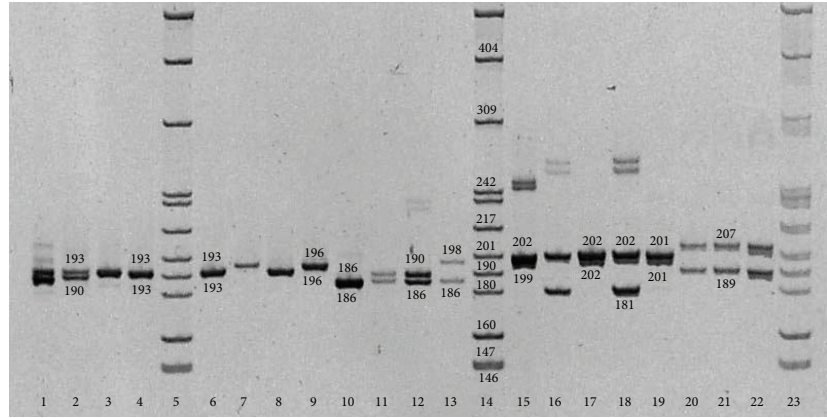

(a)

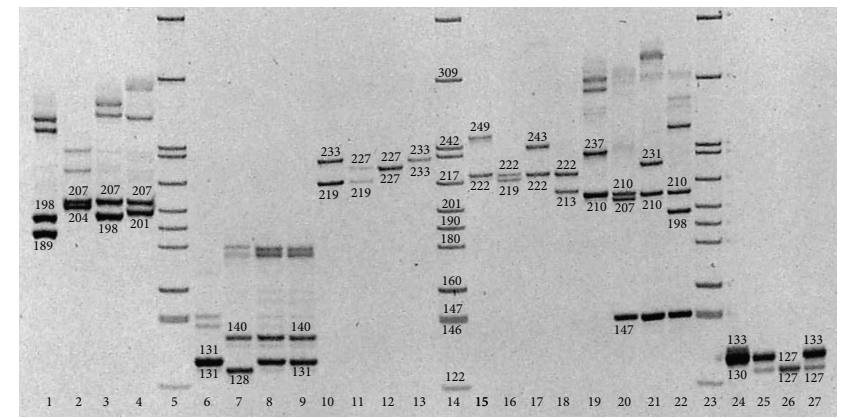

(b)

FIGURE 2: (a) Electrophoretic patterns of PCR-amplified SSR loci ORPM202, ORPM206, ORPM220, ORPM296, and ORPM312 in aspen. Loci: lanes 1-4: ORPM202; lanes 6-9: ORPM206; lanes 10-13: ORPM220; samples: 1, 6, 10, 15, and 19, aspen from native population; 2, 7, 11, 16, and 20, clone C-control; 3, 8, 12, 18, and 21, clone 47-1; 4, 9, 13, 18, and 22, clone PtV22. Lanes 5, 14, and 23: DNA molecular weight marker (DNA of E. coli plasmid pBR322, digested by restriction endonuclease HpaII). (b) Electrophoretic patterns of PCR-amplified SSR loci WPMS15, WPMS17, WPMS18, WPMS19, WPMS21, and WPMS22 in aspen. Loci: lanes 1-4: WPMS15, lanes 6-9: WPMS17, lanes 10-13: WPMS18, lanes 15-18: WPMS19, lanes 19-22: WPMS21, and lanes 24-27: WPMS22. Samples: 1, 6, 10, 15, 19, and 24, aspen from natural population; 2, 7, 11, 16, 20, and 25, clone C-control; 3, 8, 12, 16, 21, and 26, clone 47-1; 4, 9, 13, 18, 22, and 27, clone PtV22. Lanes 5, 14, and 23, DNA molecular weight marker (DNA of E. coli plasmid pBR322, digested by restriction endonuclease HpaII).

bromide solution and visualized in UV-light, graphic images were captured and saved using Doc-Print II Vilber Lourmat gel documentation system and processed in graphical editors. Fragment size was estimated by means of specialized software (Photo-Capt). DNA of E. coli plasmid pBR322, restricted by endonuclease HpaII was used as a molecular weight marker.

2.4. Statistical Analysis. Clone identity was determined using multilocus matches analysis for codominant data. Genotype probability (GP), meaning probability of appearance of particular multilocus combination in population, and probability of identity, estimating probability of random matching of two unrelated (PI) or related (PIsib) individuals by particular set of loci, were calculated based on distribution of allele frequencies in population samples.

Correspondence of observed genotype distributions for each SSR locus to the expected according Hardy-Weinberg equilibrium was tested by chi-square criterion. Allele number and observed and expected heterozygosities were calculated for each native sample. We employed Wright's $F$-statistics for assessment of genetic subdivision among the studied population samples. All the above-mentioned calculations were performed in the add-in for MS Excel, GenAlEx 6.5 [17, 18].

\section{Results and Discussion}

3.1. Development of SSR-Based Testing Systems for Genotype Identification in Aspen. For initial testing, we selected 33 heterological tri-, tetra-, penta-, and hexanucleotide microsatellite loci from two sets; series ORPM was designed first for Populus trichocarpa [15] and series WPMS was designed for Populus nigra [16]. Characteristics of these loci are given in Table 2. Initial testing was done on DNA samples from three clones (47-1, PtV22 и C-control) from an in vitro collection stored and propagated in the Pushchino branch of Shemyakin and Ovchinnikov Institute of Bioorganic Chemistry, Russian
Academy of Sciences (Pushchino, Moscow Oblast, Russia). At this stage, their variability was also tested on 20-24 specimens of wild aspen from Novosibirsk Oblast (Western Siberia, Russia) and Krasnoyarsk Krai (Middle Siberia, Russia).

As a result of the first phase of testing, 24 loci were successfully amplified and nine other loci failed to produce PCR products. Out of 24 loci that produced PCR fragments, 20 loci were shown to be variable with a number of alleles from two to nine, while four loci that have been successfully amplified were monomorphic (Table 3). After additional testing at variable PCR regimes we finally selected 14 loci with reliable amplification and substantial polymorphism level for inclusion into the test system for molecular genetic identification. Examples of the variability of the selected microsatellite loci in aspen are shown on Figures 2(a) and 2(b).

The obtained multilocus genotypes of eight elite clones and reference genotypes of wild trees from native stands are listed in Table S1 in Supplementary Material available online at http://dx.doi.org/10.1155/2015/261518. We analyzed up to 8 ramets sampled at different phases of the microclonal propagation. Within clones, genotypes were stable and unambiguously reproduced among ramets independently of the stage of propagation. After exclusion of ramets of the same genet, both elite clones and aspen genotypes from native populations included in the reference samples were $100 \%$ different. Probability of appearance of genotypes (GP: genotype probability) among elite clones varied from $2.4 \cdot 10^{-21}$ to $1.7 \cdot 10^{-11}$, among trees in a reference samples from $4.0 \cdot 10^{-24}$ to $5.8 \cdot 10^{-9}$. Probability of the occasional coincidence of two unrelated genotypes (PI: probability of identity) varied from $4.8 \cdot 10^{-10}$ in Yoshkar-Ola to $4.3 \cdot 10^{-13}$ in Prisady. Adjusted to the theoretical probability of descendance of the compared individuals from the same ancestors more conservative estimate (PIsibs) was within the range of $1.0 \cdot 10^{-4}$ in Yoshkar-Ola to $9.3 \cdot 10^{-6}$ in Voronezh. All values are quite low, so that the theoretical frequency of appearance of repeatable genotypes 


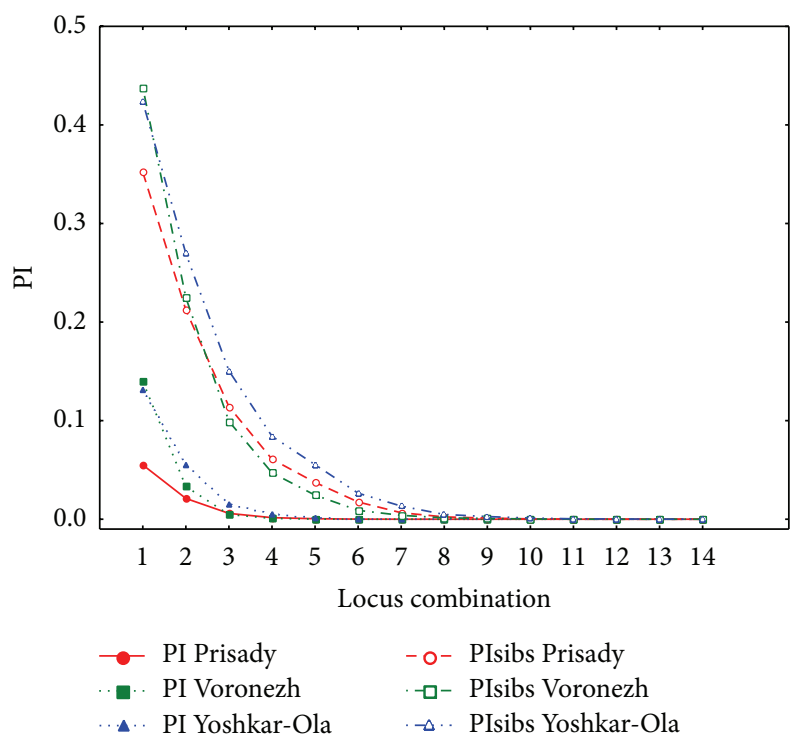

FIgURE 3: Relationship of PI and PIsibs from the number of used loci. 1 represents locus 1, 2 represents loci $1+2$, and so forth.

due to recombination of different gametes in course of seed reproduction was not exceeding about 1 accidentally found identical allele combination out of 10000 comparisons. The relationship of PI and PIsibs from the number of loci used is shown at Figure 3 and demonstrates practically negligible probability of appearance of identical genotypes while using first 7 to 8 loci selected for the inclusion into test system. Using all 14 loci ensures additional reliability and robustness of the procedure.

Development of microsatellite loci for species of the genus Populus started in late 20th century along with technologies of molecular genetic markers. In 1998, one of the first sets of primers for amplification of dinucleotide SSR loci was designed for American trembling poplar, Populus tremuloides [19]. In this paper a successful cross-amplification of the same markers for several other poplar species, $P$. deltoides, $P$. nigra, $P$. $\mathrm{x}$ canadensis, and $P$. maximowiczii, was demonstrated. The authors also postulated the broad spectrum of applications of SSR loci for different purposes including clone identification, analysis of the controlled matings, genome mapping, markerassisted selection, genetic diversity assays, and support of the programs for conservation and sustainable management of forest genetic resources. Subsequent studies provided eight other dinucleotide SSR loci for Populus tremuloides [20]. Since that time, microsatellite loci were developed for other species including $P$. nigra $[16,21]$. Some of these loci were also amplified in $P$. deltoides, $P$. trichocarpa, $P$. tremula, $P$. tremuloides, $P$. candicans, and P. lasiocarpa. Specific SSR loci primers were designed for Populus euphratica [22-25]. Later on, this set was used for development of multiplex panels used for genetic diversity estimation in this species [26, 27].

Next generation sequencing was the most efficient way of detection of tandem repeats in poplar genome and design on their base transferrable SSR primers as it was demonstrated in case of balsamic poplar, Populus trichocarpa $[15,28]$. Such universal cross-amplified loci are used for species and hybrid identification and for estimation of genetic differentiation among congeneric species [5, 9, 29-31].

Microsatellites are also useful for checking of somaclonal diversity within a pool of ramets obtained by microclonal propagation from a single donor tree [5], for identification of individual clones in an aspect of their tolerance to environmental factors [32]. We did not observe any variation in SSR patterns among ramets of the same elite clonal lineage. Nuclear microsatellites along with other classes of molecular markers are employed also for determination of ploidy level in poplars $[33,34]$, and indications of triploidy were found by us with respect to several genotypes. Triploid aspen hybrids often demonstrate increased vigor and resistance to pathogens, so this matter should be further studied by means of karyological and floating cytometry analysis.

3.2. Analysis of Clonal Structure in Native Aspen Stands. Since the very moment of the field sampling of material in wild stands we tried to avoid inclusion of clonal ramets arised as sprouts which is common for aspen. In all studied stands the same sampling scheme was applied keeping at least 15-20 m between the trees. Nevertheless, ramets of the same clone indicating common occurrence of vegetative propagations were found in all of the studied natural populations (Table S1).

Prisady. Among the studied 52 trees, we found 41 different haplotypes; one multilocus genotype was found nine times and one was found three times. We concluded that these repeated multilocus combinations resulted from sampling sprouts being ramets of the same clone.

Voronezh. Among 17 trees collected at close proximity to the site of the experimental plantation no clonal individuals were found. Thirteen trees collected at the Voronezh River bank were represented by eight genotypes: four of them were in one replicate, three were found to be two ramets of the same clone, and one genotype was found in three copies evidently originated from sprouting of ever existing progenitors. In total, we identified 25 different haplotypes in this reference population sample.

Yoshkar-Ola. Thirty-two analyzed trees combined into 13 different haplotypes identified by multilocus matches analysis; one genotype appeared twice, one genotype appeared five times, one genotype appeared seven times, and one genotype appeared nine times. Repeated genotypes evidently corresponded to ramets resulting from sprouting.

We concluded that sprouting and high level of clonality are a widespread phenomenon in native aspen stands. In aspen, as well as in many other poplars, vegetative clones are able to occupy large areas. Therefore, for the collection of a sample free of repeated clonal genotypes distances between trees should be increased up to at least $40-50 \mathrm{~m}$. However, more precise estimation of maximal spread of a single clone over stand territory also requires special exploration.

Among other applications, nuclear SSR loci were useful for the studies of clonal structure and genetic relationships among clone genotypes in native stands [35-38] or between 
TABLE 4: Parameters of genetic variability in aspen populations.

\begin{tabular}{lcccccccc}
\hline Population & & $N$ & $N_{a}$ & $N_{e}$ & $H_{O}$ & $H_{E}$ & $U H_{E}$ & \multicolumn{2}{c}{$F$} \\
\hline \multirow{2}{*}{ Prisady } & Mean & 41 & 6.429 & 3.921 & 0.631 & 0.661 & 0.669 & 0.047 \\
& s.e. & & 0.850 & 0.602 & 0.059 & 0.044 & 0.045 & 0.065 \\
Voronezh & Mean & 25 & 7.429 & 3.970 & 0.580 & 0.687 & 0.701 & 0.188 \\
& s.e. & & 1.274 & 0.584 & 0.068 & 0.035 & 0.036 & 0.076 \\
\multirow{3}{*}{ Yoshkar-Ola } & Mean & 13 & 4.643 & 2.738 & 0.522 & 0.567 & 0.590 & 0.109 \\
& s.e. & & 0.541 & 0.343 & 0.072 & 0.043 & 0.045 & 0.087 \\
Total mean & Mean & 26.333 & 6.167 & 3.543 & 0.578 & 0.639 & 0.654 & 0.115 \\
& s.e. & 1.791 & 0.558 & 0.308 & 0.038 & 0.024 & 0.025 & 0.044 \\
\hline
\end{tabular}

s.e.: standard error.

$N$ : sample size.

$N_{a}$ : mean number of alleles.

$N_{e}$ : effective number of alleles.

$H_{O}$ : observed heterozygosity.

$H_{E}$ : expected heterozygosity.

$U H_{E}$ : unbiased expected heterozygosity.

$F$ : fixation index (intrapopulation coefficient of inbreeding).

native and artificial stands [39, 40]. Variation in level of clonality was observed, for instance, in black poplar, $P$. nigra [41]. Extensive clonal assemblies were found by means of SSR analysis also in European black poplar [42], in the taxonomic continuum $P$. alba - P. $\mathrm{x}$ canescens on the Iberian Peninsula [43], and in other poplar species.

3.3. Levels of Intra- and Interpopulation Genetic Variability. All the loci of the selected set were polymorphic in all studied native population samples. Values of average allele number, effective allele number, and observed and expected heterozygosity were slightly higher in Prisady and Voronezh than in Yoshkar-Ola (Table 4).

The averaged over loci $F_{\mathrm{ST}}$ (proportion of interpopulation variation in total variation, Table 5) was $0.058 \pm$ 0.014 with the highest values observed in two loci: ORPM202 (0.164) and WPMS14 (0.162). AMOVA test showed that $6 \%$ of total molecular variation was among populations (significant, $P=0.001$ ), $10 \%$ were among individuals, and $84 \%$ were within individuals.

Microsatellites isolated from nuclear as well as chloroplast genomes were employed for the analysis of genetic diversity and genetic structure in various poplar species [42, 4460]. Levels of intrapopulation genetic diversity observed by us in native aspen stands were within the range of values commonly observed in poplars and estimated by SSR loci analysis ([47] and references therein).

A substantial number of studies employing microsatellite technique were focused on the detection of hybridization in natural [31, 46, 61-63] or artificial [64] stands of poplars. SSR loci help to reveal mechanisms of interspecific crossing and reproductive isolation [65-67]. In this study we concentrated on among-individual and among-population variation rather than on interspecific differences, but with respect to some of the studied elite clones their hybrid origin should be genetically tested using a complex set of markers but of nuclear and cytoplasmic localization. Hi-fidelity identification of interspecific hybrids and industrial clones was reported in
TABLE 5: F-statistics for three natural aspen populations.

\begin{tabular}{lccc}
\hline Locus & $F_{\mathrm{IS}}$ & $F_{\mathrm{IT}}$ & $F_{\mathrm{ST}}$ \\
\hline ORPM193 & 0.158 & 0.230 & 0.086 \\
ORPM202 & 0.514 & 0.593 & 0.164 \\
ORPM206 & 0.276 & 0.363 & 0.120 \\
ORPM220 & 0.066 & 0.096 & 0.032 \\
ORPM296 & 0.046 & 0.067 & 0.023 \\
WPMS14 & 0.074 & 0.224 & 0.162 \\
WPMS15 & -0.187 & -0.144 & 0.036 \\
WPMS16 & -0.105 & -0.083 & 0.019 \\
WPMS17 & -0.066 & -0.028 & 0.036 \\
WPMS18 & 0.305 & 0.322 & 0.025 \\
WPMS19 & -0.034 & -0.003 & 0.029 \\
WPMS20 & 0.111 & 0.131 & 0.023 \\
WPMS21 & -0.057 & -0.027 & 0.028 \\
WPMS22 & 0.563 & 0.578 & 0.035 \\
\hline Mean & 0.119 & 0.166 & 0.058 \\
S.e. & 0.060 & 0.062 & 0.014 \\
\hline
\end{tabular}

s.e.: standard error.

a considerable number of publications $[5,6,51,68-74]$. A remarkable publication reports on the genetic identity of some industrial clones of poplars previously treated as different $[68,69]$.

The practical task of identity monitoring of commercial clones in in vitro collections $[75,76]$ was similar to that employed in the present research. In all applications where reliable individual identification was required SSRs showed high effectiveness.

\section{Conclusion}

Application of nuclear microsatellite loci for genetic identification and assessment of genetic variability in aspen elite clones and native stands showed high effectiveness of 
the developed low-cost SSR-based testing system. Reliable authentication of clones ensures genetic monitoring of microclonal propagation and allows revealing clonality in native stands. We demonstrated that the same set of microsatellite loci can be successfully employed for estimation of levels of intra- and interpopulation genetic variability in aspen. Reconstruction of kinship among individual elite clones or genetic relationships of naturally mating populations are perspective tasks that can be realized in the future using the same markers.

\section{Conflict of Interests}

The authors declare that there is no conflict of interests regarding the publication of this paper.

\section{Acknowledgments}

This research is supported by the Ministry of Education and Science of the Russian Federation (Project no. 14.607.21.0044 from 22.08.2014; unique identifier RFMEFI60714X0044). The authors also thank E. M. Romanov, A. I. Shurgin, R. V. Sergeev (Volga State University of Technology, Yoshkar-Ola, Republic of Mari El, Russia), M. V. Drapaluk, A. V. Tzaralunga, A. A. Reshetnikov, E. O. Kolesnikova (Voronezh State Forestry Engineering University, Voronezh, Russia), and G. B. Kolganikhina (Institute of Forest Science RAS, Uspenskoe, Moscow region, Russia), for their help with sample collection in native stands. The authors are also grateful to M. Zeps, D. Auzenbaha, and A. Gailis (Latvian State Forest Research Institute "Silava," Salaspils, Latvia) for sharing biological material and information on aspen elite clones.

\section{References}

[1] C. C. Giri, B. Shyamkumar, and C. Anjaneyulu, "Progress in tissue culture, genetic transformation and applications of biotechnology to trees: an overview," Trees, vol. 18, no. 2, pp. 115$135,2004$.

[2] K. A. Shestibratov, V. G. Lebedev, and A. I. Miroshnikov, "Forest biotechnology: methods, technologies, and perspectives," Biotechnology in Russia, vol. 5, pp. 1-34, 2008.

[3] T. A. Thorpe, I. S. Harry, and P. P. Kumar, "Application of micropropagation to forestry," in Micropropagation. Technology and Application, pp. 311-336, Springer, Amsterdam, The Netherlands, 1991.

[4] B. Ziegenhagen and M. Fladung, "DNA markers for identification and evaluation of genetic resources in forest trees: case studies in Abies, Picea and Populus," in Molecular Marker Systems in Plant Breeding and Crop Improvement, pp. 413-429, Springer, Berlin, Germany, 2005.

[5] M. H. Rahman and O. P. Rajora, "Microsatellite DNA somaclonal variation in micropropagated trembling aspen (Populus tremuloides)," Plant Cell Reports, vol. 20, no. 6, pp. 531536, 2001.

[6] M. H. Rahman and O. P. Rajora, "Microsatellite DNA fingerprinting, differentiation, and genetic relationships of clones, cultivars, and varieties of six poplar species from three sections of the genus Populus," Genome, vol. 45, no. 6, pp. 1083-1094, 2002.
[7] O. P. Rajora and M. H. Rahman, "Microsatellite DNA markers and their usefulness in poplars, and conservation of microsatellite DNA loci in Salicaceae," in Genetic Response of Forest Systems to Changing Environmental Conditions, vol. 70 of Forestry Sciences, pp. 105-115, Springer, Dordrecht, The Netherlands, 2001.

[8] O. P. Rajora and M. H. Rahman, "Microsatellite DNA and RAPD fingerprinting, identification and genetic relationships of hybrid poplar (Populus x canadensis) cultivars," Theoretical and Applied Genetics, vol. 106, no. 3, pp. 470-477, 2003.

[9] H. Schroeder and M. Fladung, "SSR and SNIP markers for the identification of clones, hybrids and species within the genus Populus," Silvae Genetica, vol. 59, no. 6, pp. 257-263, 2010.

[10] K. A. Shestibratov, V. G. Lebedev, and A. B. Azarova, "Method of in vitro preparation of microshoots of ash, aspen, willow for subsequent rooting under ex vitro conditions," Patent of Russian Federation no. 2565806 of 20.10.2015, 2012.

[11] S. N. Bagaev and E. S. Bagaev, "A genetic reserve of giant aspen," Lesnoe Khozyaistvo, no. 4, pp. 45-48, 1990.

[12] M. Zeps, D. Auzenbaha, A. Gailis, A. Treimanis, and U. Grinfelds, "Evaluation and selection of hybrid aspen (Populus tremuloides $\times$ Populus tremula) clones," Mezzinatne, vol. 18, no. 51, pp. 19-34, 2008.

[13] M. E. Devey, J. C. Beil, D. N. Smith, D. B. Neale, and G. F. Moran, "A genetic linkage map for Pinus radiata based on RFLP, RAPD, and microsatellite markers," Theoretical and Applied Genetics, vol. 92, no. 6, pp. 673-679, 1996.

[14] J. J. Doyle and J. L. Doyle, "Isolation of plant DNA from fresh tissue," Focus, vol. 12, no. 1, pp. 12-15, 1990.

[15] G. A. Tuskan, L. E. Gunter, Z. K. Yang, T. Yin, M. M. Sewell, and S. P. DiFazio, "Characterization of microsatellites revealed by genomic sequencing of Populus trichocarpa," Canadian Journal of Forest Research, vol. 34, no. 1, pp. 85-93, 2004.

[16] M. J. M. Smulders, J. Van Der Schoot, P. Arens, and B. Vosman, "Trinucleotide repeat microsatellite markers for black poplar (Populus nigra L.)," Molecular Ecology Notes, vol. 1, no. 3, pp. 188-190, 2001.

[17] R. Peakall and P. E. Smouse, "GENALEX 6: genetic analysis in Excel. Population genetic software for teaching and research," Molecular Ecology Notes, vol. 6, no. 1, pp. 288-295, 2006.

[18] R. Peakall and P. E. Smouse, "GenALEx 6.5: genetic analysis in Excel. Population genetic software for teaching and researchan update," Bioinformatics, vol. 28, no. 19, Article ID bts460, pp. 2537-2539, 2012.

[19] S. Dayanandan, O. P. Rajora, and K. S. Bawa, "Isolation and characterization of microsatellites in trembling aspen (Populus tremuloides)," Theoretical and Applied Genetics, vol. 96, no. 6-7, pp. 950-956, 1998.

[20] M. H. Rahman, S. Dayanandan, and O. P. Rajora, "Microsatellite DNA markers in Populus tremuloides," Genome, vol. 43, no. 2, pp. 293-297, 2000.

[21] J. van der Schoot, M. Pospíśková, B. Vosman, and M. J. M. Smulders, "Development and characterization of microsatellite markers in black poplar (Populos nigra L.)," Theoretical and Applied Genetics, vol. 101, no. 1-2, pp. 317-322, 2000.

[22] Q. Du, C. Gong, W. Pan, and D. Zhang, "Development and application of microsatellites in candidate genes related to wood properties in the Chinese white poplar (Populus tomentosa Carr.)," DNA Research, vol. 20, no. 1, pp. 31-44, 2013.

[23] F. K. Du, F. Xu, H. Qu, S. Feng, J. Tang, and R. Wu, "Exploiting the transcriptome of Euphrates poplar, Populus euphratica 
(Salicaceae) to develop and characterize new EST-SSR markers and construct an EST-SSR databas," PLoS ONE, vol. 8, no. 4, Article ID e61337, 2013.

[24] Q. Du, W. Pan, B. Xu, B. Li, and D. Zhang, "Polymorphic simple sequence repeat (SSR) loci within cellulose synthase (PtoCesA) genes are associated with growth and wood properties in Populus tomentosa," New Phytologist, vol. 197, no. 3, pp. 763-776, 2013.

[25] Y. Wu, J. Wang, and J. Liu, "Development and characterization of microsatellite markers in Populus euphratica (Populaceae)," Molecular Ecology Resources, vol. 8, no. 5, pp. 1142-1144, 2008.

[26] E. Pascal, F. Steffen, and S. Martin, "Development of two microsatellite multiplex PCR systems for high throughput genotyping in Populus euphratica," Journal of Forestry Research, vol. 20, no. 3, pp. 195-198, 2009.

[27] F. Xu, S. Feng, R. Wu, and F. K. Du, "Two highly validated SSR multiplexes (8-plex) for Euphrates' poplar, Populus euphratica (Salicaceae)," Molecular Ecology Resources, vol. 13, no. 1, pp. 144153, 2013.

[28] T. M. Yin, X. Y. Zhang, L. E. Gunter et al., "Microsatellite primer resource for Populus developed from the mapped sequence scaffolds of the Nisqually-1 genome," New Phytologist, vol. 181, no. 2, pp. 498-503, 2009.

[29] T. Bruegmann and M. Fladung, "Potentials and limitations of the cross-species transfer of nuclear microsatellite marker in six species belonging to three sections of the genus Populus L," Tree Genetics \& Genomes, vol. 9, no. 6, pp. 1413-1421, 2013.

[30] K. Chen, Y. Peng, Y. Wang, H. Korpelainen, and C. Li, “Genetic relationships among poplar species in section Tacamahaca (Populus L.) from western Sichuan, China," Plant Science, vol. 172, no. 2, pp. 196-203, 2007.

[31] M. J. M. Smulders, R. Beringen, R. Volosyanchuk et al., "Natural hybridisation between Populus nigra L. and P. x canadensis Moench. Hybrid offspring competes for niches along the Rhine river in the Netherlands," Tree Genetics \& Genomes, vol. 4, no. 4, pp. 663-675, 2008.

[32] M. D. Madritch, S. L. Greene, and R. L. Lindroth, "Genetic mosaics of ecosystem functioning across aspen-dominated landscapes," Oecologia, vol. 160, no. 1, pp. 119-127, 2009.

[33] C.-B. Dong, Y.-J. Suo, and X.-Y. Kang, "Assessment of the genetic composition of triploid hybrid Populus using SSR markers with low recombination frequencies," Canadian Journal of Forest Research, vol. 44, no. 7, pp. 692-699, 2014.

[34] F. Kong, J. Liu, Y. Chen, Z. Wan, and T. Yin, "Marker-aided selection of polyploid poplars," Bioenergy Research, vol. 6, no. 3, pp. 984-990, 2013.

[35] N. Chenault, S. Arnaud-Haond, M. Juteau et al., "SSR-based analysis of clonality, spatial genetic structure and introgression from the Lombardy poplar into a natural population of Populus nigra L. along the Loire River," Tree Genetics \& Genomes, vol. 7, no. 6, pp. 1249-1262, 2011.

[36] J. DeWoody, C. A. Rowe, V. D. Hipkins, and K. E. Mock, “'Pando' lives: molecular genetic evidence of a giant aspen clone in Central Utah," Western North American Naturalist, vol. 68, no. 4, pp. 493-497, 2008.

[37] K. E. Mock, C. A. Rowe, M. B. Hooten, J. Dewoody, and V. D. Hipkins, "Clonal dynamics in western North American aspen (Populus tremuloides)," Molecular Ecology, vol. 17, no. 22, pp. 4827-4844, 2008.

[38] G. T. Slavov, S. Leonardi, W. T. Adams, S. H. Strauss, and S. P. Difazio, "Population substructure in continuous and fragmented stands of Populus trichocarpa," Heredity, vol. 105, no. 4, pp. 348-357, 2010.

[39] G. Brundu, R. Lupi, I. Zapelli et al., "The origin of clonal diversity and structure of Populus alba in Sardinia: evidence from nuclear and plastid microsatellite markers," Annals of Botany, vol. 102, no. 6, pp. 997-1006, 2008.

[40] L. I. Suvanto and T. B. Latva-Karjanmaa, "Clone identification and clonal structure of the European aspen (Populus tremula)," Molecular Ecology, vol. 14, no. 9, pp. 2851-2860, 2005.

[41] N. Barsoum, E. Muller, and L. Skot, "Variations in levels of clonality among Populus nigra L. stands of different ages," Evolutionary Ecology, vol. 18, no. 5-6, pp. 601-624, 2004.

[42] M. J. M. Smulders, J. E. Cottrell, F. Lefèvre et al., "Structure of the genetic diversity in black poplar (Populus nigra L.) populations across European river systems: consequences for conservation and restoration," Forest Ecology and Management, vol. 255, no. 5-6, pp. 1388-1399, 2008.

[43] L. Santos-del-Blanco, A. I. de-Lucas, S. C. González-Martínez, R. Sierra-de-Grado, and E. Hidalgo, "Extensive Clonal Assemblies in Populus alba and Populus x canescens from the Iberian Peninsula," Tree Genetics \& Genomes, vol. 9, no. 2, pp. 499-510, 2013.

[44] A. Alimohamadi, F. Asadi, and R. T. Aghdaei, "Genetic diversity in Populus nigra plantations from west of Iran," Annals of Forest Research, vol. 55, no. 2, pp. 165-178, 2012.

[45] C. M. Callahan, C. A. Rowe, R. J. Ryel, J. D. Shaw, M. D. Madritch, and K. E. Mock, "Continental-scale assessment of genetic diversity and population structure in quaking aspen (Populus tremuloides)," Journal of Biogeography, vol. 40, no. 9, pp. 1780-1791, 2013.

[46] S. Castiglione, A. Cicatelli, R. Lupi et al., "Genetic structure and introgression in riparian populations of Populus alba L," Plant Biosystems, vol. 144, no. 3, pp. 656-668, 2010.

[47] C. T. Cole, "Allelic and population variation of microsatellite loci in aspen (Populus tremuloides)," New Phytologist, vol. 167, no. 1, pp. 155-164, 2005.

[48] D. De Carvalho, P. K. Ingvarsson, J. Joseph et al., "Admixture facilitates adaptation from standing variation in the European aspen (Populus tremula L.), a widespread forest tree," Molecular Ecology, vol. 19, no. 8, pp. 1638-1650, 2010.

[49] Q. Du, B. Wang, Z. Wei, D. Zhang, and B. Li, "Genetic diversity and population structure of Chinese white poplar (Populus tomentosa) revealed by SSR markers," Journal of Heredity, vol. 103, no. 6, pp. 853-862, 2012.

[50] P. Eusemann, A. Petzold, N. Thevs, and M. Schnittler, "Growth patterns and genetic structure of Populus euphratica Oliv. (Salicaceae) forests in NW China-implications for conservation and management," Forest Ecology and Management, vol. 297, pp. 27-36, 2013.

[51] T. Fossati, F. Grassi, F. Sala, and S. Castiglione, "Molecular analysis of natural populations of Populus nigra L. intermingled with cultivated hybrids," Molecular Ecology, vol. 12, no. 8, pp. 2033-2043, 2003.

[52] K. M. Lee, Y. Y. Kim, and J. O. Hyun, "Genetic variation in populations of Populus davidiana Dode based on microsatellite marker analysis," Genes and Genomics, vol. 33, no. 2, pp. 163-171, 2011.

[53] D. MacAya-Sanz, M. Heuertz, U. López-de-Heredia et al., "The Atlantic-Mediterranean watershed, river basins and glacial history shape the genetic structure of Iberian poplars," Molecular Ecology, vol. 21, no. 14, pp. 3593-3609, 2012. 
[54] Y. H. Peng, Z. X. Lu, K. Chen, O. Luukkanen, H. Korpelainen, and C. Y. Li, "Population genetic survey of Populus cathayana originating from Southeastern Qinghai-Tibetan plateau of China based on SSR markers," Silvae Genetica, vol. 54, no. 3, pp. 116-122, 2005.

[55] D. Shen, W. Bo, F. Xu, and R. Wu, "Genetic diversity and population structure of the Tibetan poplar (Populus szechuanica var. tibetica) along an altitude gradient," BMC Genetics, vol. 15, supplement 1, p. S11, 2014.

[56] J. Wang, Y. Wu, G. Ren, Q. Guo, J. Liu, and M. Lascoux, “Genetic differentiation and delimitation between ecologically diverged Populus euphratica and P. pruinosa," PLoS ONE, vol. 6, no. 10, Article ID e26530, 2011.

[57] J. Wang, Z. Li, Q. Guo, G. Ren, and Y. Wu, "Genetic variation within and between populations of a desert poplar (Populus euphratica) revealed by SSR markers," Annals of Forest Science, vol. 68, no. 6, pp. 1143-1149, 2011.

[58] Z. Wei, Q. Du, J. Zhang, B. Li, and D. Zhang, "Genetic diversity and population structure in Chinese indigenous poplar (Populus simonii) populations using microsatellite markers," Plant Molecular Biology Reporter, vol. 31, no. 3, pp. 620-632, 2013.

[59] J. Wyman, A. Bruneau, and M.-F. Tremblay, "Microsatellite analysis of genetic diversity in four populations of Populus tremuloides in Quebec," Canadian Journal of Botany, vol. 81, no. 4, pp. 360-367, 2003.

[60] L. Zhang, P.-P. Jiao, and Z.-J. Li, "Genetic diversity of Populus pruinosa populations in Xinjiang of China based on SSR analysis," Shengtaixue Zazhi, vol. 31, no. 11, pp. 2755-2761, 2012.

[61] T. Fossati, G. Patrignani, I. Zapelli, M. Sabatti, F. Sala, and S. Castiglione, "Development of molecular markers to assess the level of introgression of Populus tremula into $P$. alba natural populations," Plant Breeding, vol. 123, no. 4, pp. 382-385, 2004.

[62] C. Lexer, M. F. Fay, J. A. Joseph, M.-S. Nica, and B. Heinze, "Barrier to gene flow between two ecologically divergent Populus species, $P$. alba (white poplar) and $P$. tremula (European aspen): the role of ecology and life history in gene introgression," Molecular Ecology, vol. 14, no. 4, pp. 1045-1057, 2005.

[63] C. Lexer, C. A. Buerkle, J. A. Joseph, B. Heinze, and M. F. Fay, "Admixture in European Populus hybrid zones makes feasible the mapping of loci that contribute to reproductive isolation and trait differences," Heredity, vol. 98, no. 2, pp. 74-84, 2007.

[64] A. Vanden Broeck, V. Storme, J. E. Cottrell et al., "Gene flow between cultivated poplars and native black poplar (Populus nigra L.): a case study along the river Meuse on the DutchBelgian border," Forest Ecology and Management, vol. 197, no. 1-3, pp. 307-310, 2004.

[65] C. Lexer, J. A. Joseph, M. Van Loo et al., "Genomic admixture analysis in European Populus spp. reveals unexpected patterns of reproductive isolation and mating," Genetics, vol. 186, no. 2, pp. 699-712, 2010.

[66] D. Macaya-Sanz, L. Suter, J. Joseph et al., "Genetic analysis of post-mating reproductive barriers in hybridizing European Populus species," Heredity, vol. 107, no. 5, pp. 478-486, 2011.

[67] J.-F. Zhang, Z.-Z. Wei, D. Li, and B. Li, "Using SSR markers to study the mechanism of $2 \mathrm{n}$ pollen formation in Populus $x$ euramericana (Dode) Guinier and P. x popularis," Annals of Forest Science, vol. 66, no. 5, 2009.

[68] F. Bekkaoui, B. Mann, and B. Schroeder, "Application of DNA markers for the identification and management of hybrid poplar accessions," Agroforestry Systems, vol. 59, no. 1, pp. 53-59, 2003.

[69] A. I. De-Lucas, J. C. Santana, P. Recio, and E. Hidalgo, "SSRbased tool for identification and certification of commercial
Populus clones in Spain," Annals of Forest Science, vol. 65, no. 1, p. 107, 2008.

[70] I. Gomez and C.-J. Tsai, "Identification of microsatellite markers for diagnostic genotyping Populus fremontii x angustifolia backcross hybrids," Plant Biology, pp. 236-236, 2007.

[71] H. Liesebach, V. Schneck, and E. Ewald, "Clonal fingerprinting in the genus Populus L. by nuclear microsatellite loci regarding differences between sections, species and hybrids," Tree Genetics \& Genomes, vol. 6, no. 2, pp. 259-269, 2010.

[72] G. Rathmacher, M. Niggemann, H. Wypukol, K. Gebhardt, B. Ziegenhagen, and R. Bialozyt, "Allelic ladders and reference genotypes for a rigorous standardization of poplar microsatellite data," Trees-Structure and Function, vol. 23, no. 3, pp. 573583, 2009.

[73] A. Vanden Broeck, J. Cottrell, P. Quataert et al., "Paternity analysis of Populus nigra L. offspring in a Belgian plantation of native and exotic poplars," Annals of Forest Science, vol. 63, no. 7, pp. 783-790, 2006.

[74] N. Wheeler, P. Payne, V. Hipkins, R. Saich, S. Kenny, and G. Tuskan, "Polymix breeding with paternity analysis in Populus: a test for differential reproductive success (DRS) among pollen donors," Tree Genetics \& Genomes, vol. 2, no. 1, pp. 53-60, 2006.

[75] T. Fossati, I. Zapelli, S. Bisoffi et al., "Genetic relationships and clonal identity in a collection of commercially relevant poplar cultivars assessed by AFLP and SSR," Tree Genetics \& Genomes, vol. 1, no. 1, pp. 11-19, 2005.

[76] A. Gómez, J. A. Manzanera, E. Aguiriano, J. M. Grau, and M. A. Bueno, "SSR markers for monitoring an in vitro core collection of Populus tremula," Silvae Genetica, vol. 52, no. 5-6, pp. 224229, 2003. 

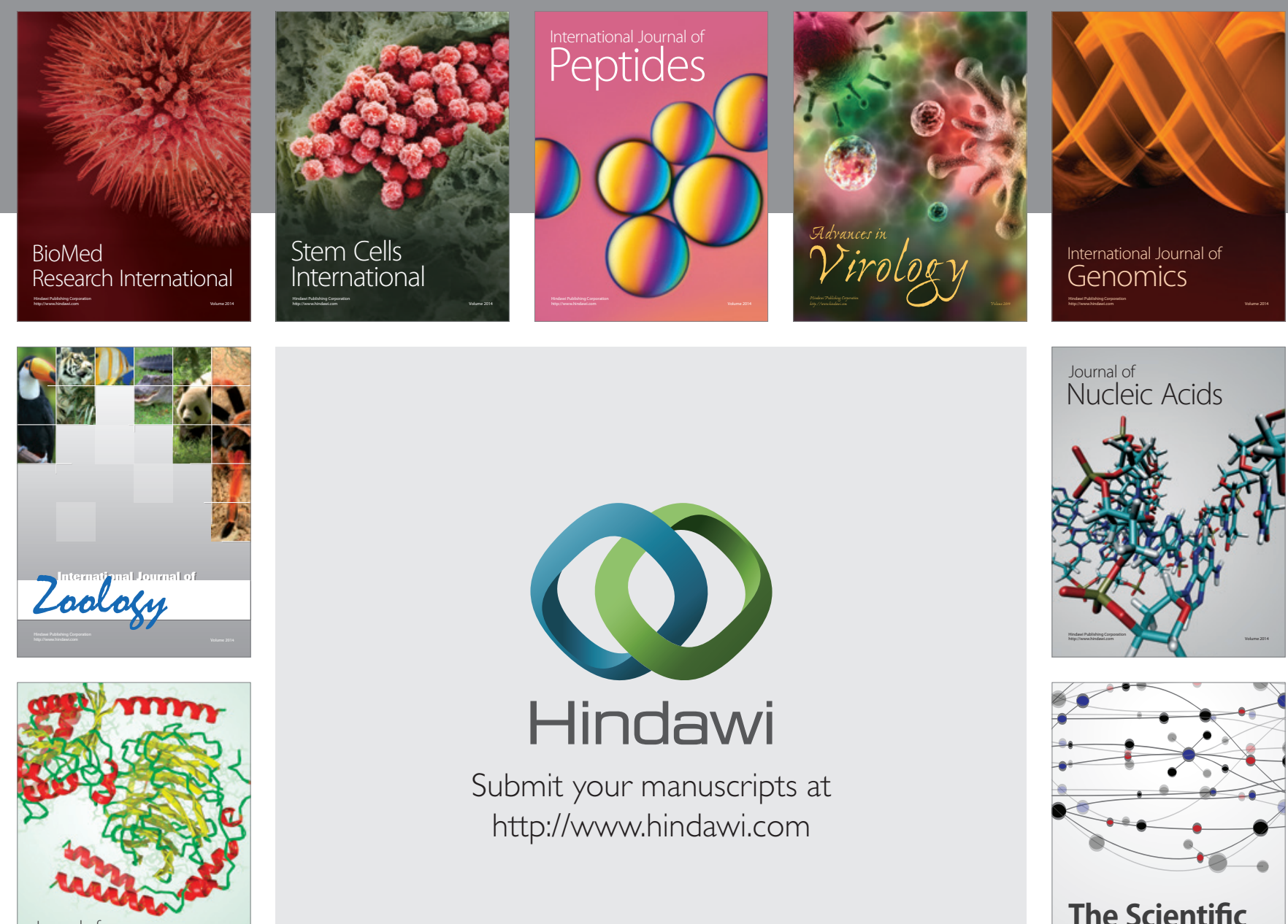

Submit your manuscripts at

http://www.hindawi.com

Journal of
Signal Transduction
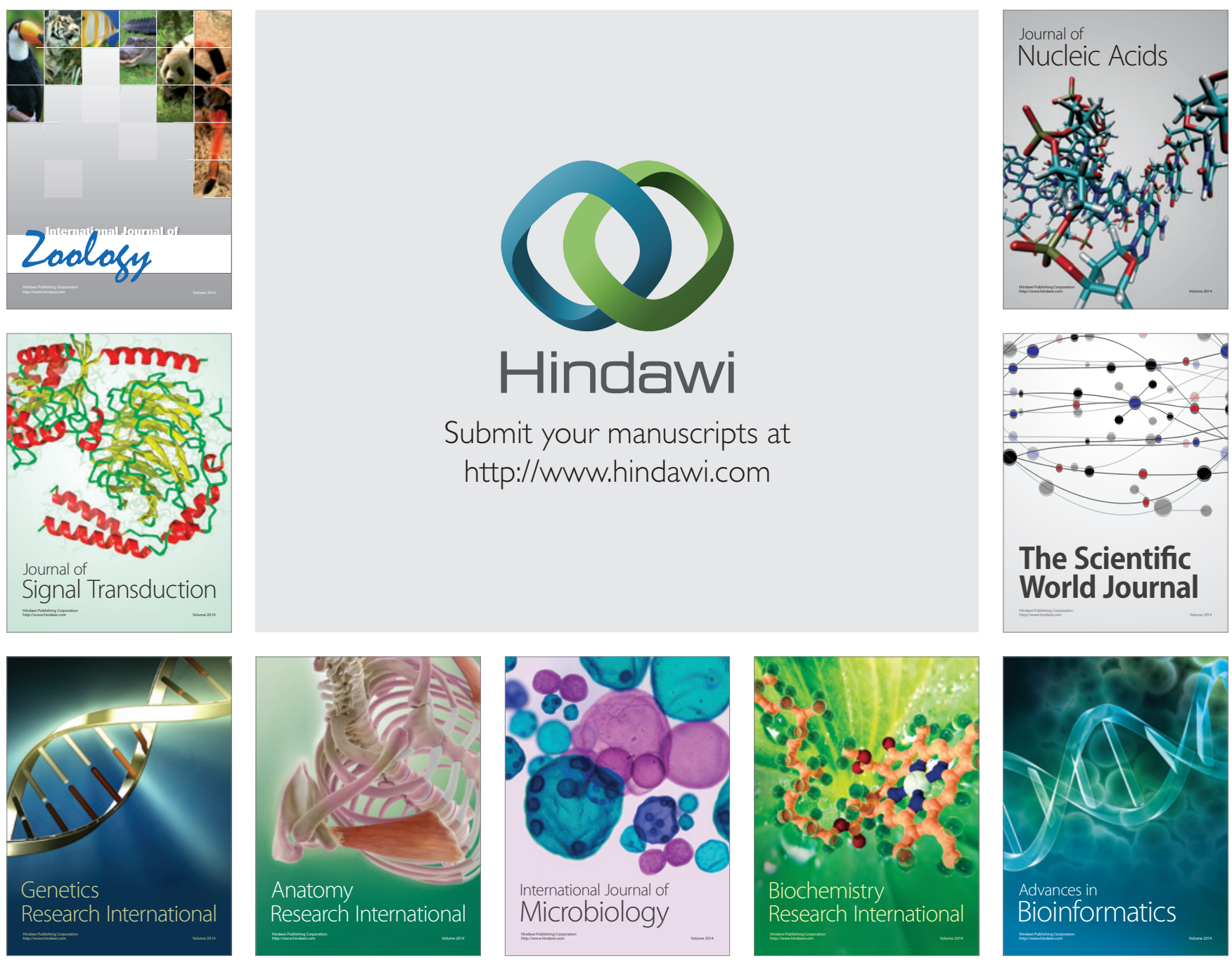

The Scientific World Journal
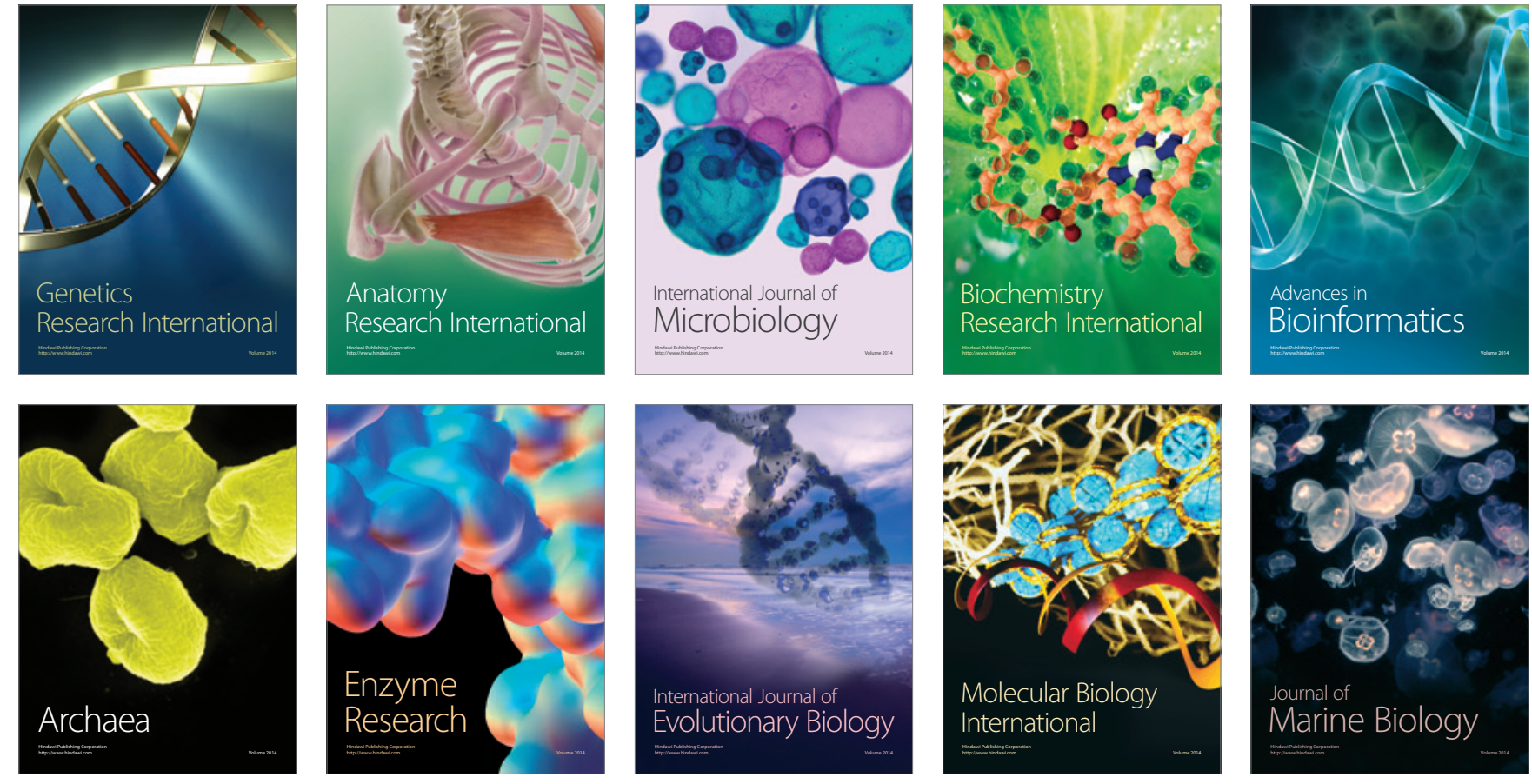